\title{
Noninvasive Markers of Oxidative DNA Stress, RNA Degradation and Protein Degradation Are Differentially Correlated With Resting Metabolic Rate and Energy Intake in Children and Adolescents
}

\author{
HEINRICH TOPP, GERHARD FUSCH, GERHARD SCHÖCH, AND CHRISTOPH FUSCH
}

\author{
Neonatology [H.T., G.F., C.F.], University Children's Hospital, 17487 Greifswald, Germany; Business Unit Parenteral Nutrition [H.T.], \\ Fresenius Kabi Deutschland GmbH, 61440 Oberursel, Germany; Research Institute for Child Nutrition [G.S.], 44225 Dortmund, Germany
}

\begin{abstract}
Urinary excreted RNA and DNA catabolites are used as noninvasive markers for metabolic processes: 8-oxo-2'deoxyguanosine (8-oxodG) potentially represents oxidative stress to DNA/deoxyribonucleotidetriphosphate pool, modified ribonucleoside pseudouridine $(\psi)$ originating mainly from degraded rRNA and tRNA reflects RNA turnover. Modified amino acid $\gamma$-carboxyglutamic acid (Gla) stems from degraded proteins reflecting turnover of proteins. Aim of the present study was to investigate (44 healthy males, 3-18 y) how excretion rates of 8 -oxodG, $\psi$, and Gla are related to resting metabolic rate and energy intake. Excretion rates of 8-oxodG ( $\mathrm{pmol} / \mathrm{kg} / \mathrm{d}), \psi(\mu \mathrm{mol} / \mathrm{kg} / \mathrm{d})$, and Gla $(\mu \mathrm{mol} / \mathrm{kg} / \mathrm{d})$ were significantly correlated with resting metabolic rate $(\mathrm{kJ} / \mathrm{kg} / \mathrm{d}): \mathrm{r}^{2}=$ $0.108(p=0.029), 0.691$ and $0.552(p<0.0001)$, respectively. Excretion rates of 8 -oxodG, $\psi$, and Gla were also significantly correlated with energy intake $(\mathrm{kJ} / \mathrm{kg} / \mathrm{d}): \mathrm{r}^{2}=0.108(p=0.036)$, 0.602 and $0.462(p<0.0001)$. 8-oxodG and Gla excretion was significantly correlated with $\psi$ excretion: $\mathrm{r}^{2}=0.174(p=0.005)$ and 0.709 ( $p<0.0001)$. These results indicate close relationships between whole-body RNA and protein degradation and metabolic rate. The relationship between 8-oxodG excretion and metabolic rate, however, is less strong suggesting that factors other than metabolic rate considerably affect the oxidative stress to DNA. (Pediatr Res 64: 246-250, 2008)
\end{abstract}

Q-oxo-2'-deoxyguanosine (8-oxodG) can be formed in ODNA by reactive oxygen species (ROS). Renal excretion of 8-oxodG has been considered as a noninvasive marker of oxidative DNA damage in (patho-) physiologic and nutritional studies (e.g., Refs.1-19). The respiratory chain in mitochondria is one source for the formation of ROS (20-22) and it may be hypothesized that the formation and urinary excretion of 8-oxodG is related to consumption of $\mathrm{O}_{2}$. Indeed, a close association between 24-h $\mathrm{O}_{2}$ consumption and 8-oxodG excretion has been described in a group of 33 smoking and nonsmoking premenopausal women (23). Another study of the same research group described a close association between the urinary excretion rate of 8-oxodG and the metabolic rate in four various mammalian species (24). Also subsequently performed investigations in six different species ranging in body weight (BW) from 0.02 (mouse) to $75 \mathrm{~kg}$ (human) showed

Received January 2, 2008; accepted April 10, 2008

Correspondence: Christoph Fusch, M.D., University Children's Hospital, Soldmannstrasse 15, D-17475 Greifswald, Germany; e-mail: fusch@uni-greifswald.de highly significant correlations between the excretion of 8-oxo$\mathrm{dG} /$ creatinine and the specific metabolic rate (25). However, we have found no such close association when comparing the 8 -oxodG excretion and the resting metabolic rate (RMR) between 18-y-old humans and 320-g rats; RMR/d/kg BW of the latter was higher by a factor of 4 times but the excretion of 8-oxodG was similar in both species (26). In that study, RMR was estimated via BWs by using an empirical formula or a figure from literature in the case of humans and rats, respectively (26), and RMR represented the specific metabolic rate under fasting and more inactive conditions. Hence, our results in man and rat were different to those reported in the abovementioned studies (24-25). However, our results of a similar 8-oxodG excretion in man and rat are consistent with corresponding results published by Helbock et al. (4). In a recent study performed in 14 children (median age $11 \mathrm{y}$ ) and 16 adults (median age $30 \mathrm{y}$ ) of both genders, we found also no significant correlation between RMR per $24 \mathrm{~h}$ per $\mathrm{kg}$ lean body mass (RMR/d/kg LBM), as measured by indirect calorimetry and dual-energy $\mathrm{x}$-ray absorptiometry, and excretion of 8-oxodG/d/kg LBM (27).

In contrast, in a subgroup (four children, six adults) of the latter study, strong correlations were found between RMR and RNA turnover, as measured by whole-body degradation rates of tRNA and rRNA, when related to LBM (27). In this study, the degradation rate of tRNA was determined by measuring the urinary excretion of the tRNA-specific catabolite $N^{2}$, $N^{2}$-dimethylguanosine $\left(\mathrm{m}_{2}{ }^{2} \mathrm{G}\right)$. The degradation rate of rRNA was determined on the basis of the excretion of pseudouridine $(\psi)$, as described in detail elsewhere (28). From these and former findings in different other mammalian species of various BWs $(29,30)$, it may be concluded that noninvasively determined degradation rates of t- and rRNA as well as the excretion rate of $\psi$ seem to be appropriate indicators of RMR at least in healthy subjects $(27,28)$.

\footnotetext{
Abbreviations: BW, body weight; dG, deoxyguanosine; dNTP, deoxyribonucleotidetriphosphate; EI, energy intake by food; Gla, $\gamma$-carboxyglutamic acid; LBM, lean body mass; 8-oxodG, 8-oxo-2'-deoxyguanosine (8-oxo-7,8dihydro- $2^{\prime}$-deoxyguanosine); 8-oxoGua, 8-oxoguanine (8-oxo-7,8-dihydroguanine); $\boldsymbol{\psi}$, pseudouridine; RMR, resting metabolic rate; ROS, reactive oxygen species
} 
Whole-body protein turnover as measured using stable isotope techniques was also shown to be strongly correlated with calculated RMR in different mammalian species of various BWs (31). Furthermore, it could be shown in various mammals and in humans that calculated RMR was strongly related to the degradation rate of muscle protein and proteins containing the modified amino acid $\gamma$-carboxyglutamic acid (Gla), namely prothrombin, blood coagulation factors VII, IX, and $\mathrm{X}$, proteins $\mathrm{C}, \mathrm{S}$, and $\mathrm{Z}$ as well as matrix Gla protein and osteocalcin $(29,30,32)$. The degradation of muscle protein and Gla-containing proteins was also determined noninvasively by measuring urinary excretion of the modified amino acids 3-methylhistidine and Gla, respectively $(29,32)$.

Whereas, strong correlations between RMR and wholebody RNA and protein degradation rates have been concordantly described (27-32), the results concerning 8-oxodG excretion and metabolic rate are somewhat controversial (2327). Therefore, the aim of the present basic research study was to compare in different groups that were fairly homogenously composed with respect to age, gender, lifestyle, etc. (see "Discussion") the correlations of urinary excretion of 8-oxodG (potential marker for oxidative stress to DNA and deoxyribonucleotidetriphosphate (dNTP) pool, cf. discussion), $\psi$ (marker for RNA degradation), and Gla (marker for protein degradation) with calculated RMR and energy intake (EI), respectively.

\section{MATERIALS AND METHODS}

Subjects and study design. The study was carried out in accordance with the Declaration of Helsinki (1989) of the World Medical Association and was approved by the Ethical Committee of the University of Bonn, Germany; written informed consent was obtained from the parents of the children. The subjects were participants of the Dortmund Nutritional and Anthropometric Longitudinally Designed Study (DONALD), in which the normal development of children and adolescents is investigated (33). Forty-four healthy boys in five age groups $(3,6,10,14$ and $18 \mathrm{y})$ were enrolled in the present study. Each age group, with the exception of the 6-y-old boys $(n=8)$, consisted of nine subjects. All subjects were nonsmokers living under normal conditions at home with food intake ad libitum. EI intake was determined by weighing the ingested food components over 3 consecutive days and calculating the energy of the ingested food using published data on energy content of various food components $(33,34)$. Pooled 24 -h urine was collected with controlled collection times (1384 $\pm 134 \mathrm{~min})$ during the $2 \mathrm{nd}$ or $3 \mathrm{rd}$ day in the period of the nutritional protocol. Urine samples were collected around the birthday, respectively, and frozen at $-20^{\circ} \mathrm{C}$ until analysis. RMR was calculated on the basis of the BW using following formulas after Schofield (35).
For 3-and 6-y-old males: RMR $(\mathrm{kJ} / \mathrm{d} / \mathrm{kg} \mathrm{BW})=(0.095 \mathrm{BW}+2.110) \times$ 1000/BW; for 10-, 14-, and 18-y-old males: RMR(kJ/d/kg BW $)=(0.074 \mathrm{BW}+$ $2.754) \times 1000 / \mathrm{BW}$.

Determination of 8-oxo-2'-deoxyguanosine (8-oxodG), pseudouridine $(\psi)$, and $\gamma$-carboxyglutamic acid (Gla) and statistical analysis. 8-oxodG was determined using a solid phase extraction and high performance liquid chromatography (HPLC) method with electrochemical detection as has been described before (26). The method used for measurement of $\psi$ is based on prefractionation of $\psi$ using a boronate gel followed by reversed phase HPLC with UV detection $(36,37)$. Gla was determined using a precolumnderivatization of Gla with $o$-phthal-dialdehyde followed by reversed HPLC with fluorescence detection as described previously (32). Linear regression analysis were performed using SPSS for Windows 10.0; SPSS GmbH Software, Munich, Germany. Level of significance was set to $p<0.05$. Differences of RMR, excretion of $\psi$, Gla, and 8-oxodG between the most distant age groups ( 3 and 18 -y-old boys) were statistically tested using Wilcoxon-Mann-Whitney- $U$ test, BIAS for Windows, version 8, EpsilonVerlag, Germany.

\section{RESULTS}

Mean EI per $24 \mathrm{~h}$ per kg BW decreased continuously from $3-18$-y-old subjects and was by a factor of two higher in the youngest group compared with oldest one (Table 1). Calculated RMR dropped similarly (Table 1, Fig. 1). RMR and EI per $24 \mathrm{~h}$ per kg BW were strongly correlated $\left(\mathrm{r}^{2}=0.771, p<\right.$ $0.0001)$. Mean urinary excretion rate of the ribonucleoside $\psi$ per $24 \mathrm{~h}$ per $\mathrm{kg}$ BW also decreased continuously and was approximately 1.6-fold higher in the 3-y-old subjects compared with the 18-y-old ones (Table 1, Fig. 1). Excretion of $\psi$ was strongly correlated with RMR and with EI (Table 2, Fig. 2 A). Excretion of the amino acid Gla decreased similar to $\psi$ from youngest to oldest subjects (Table 1, Fig. 1) and was significantly correlated with RMR, with EI, and with the excretion of $\psi$ (Table 2, Fig. 2B). In contrast, excretion rates of 8-oxodG seemed not to decrease continuously with age but showed relatively high standard deviations in the different age groups (Table 1, Fig. 1). Whereas RMR, excretion of $\psi$ and Gla were significantly different $(p<0.0001)$ between the 3and 18 -y-old subjects, no significant difference in the case of 8 -oxodG was found between these two age groups $(p=0.34)$. Excretion of 8-oxodG was weak but significantly $\left(\mathrm{r}^{2}=0.108\right.$, $p=0.029$ and $p=0.036)$ correlated with RMR and EI, and more strongly correlated $\left(\mathrm{r}^{2}=0.174, p=0.005\right)$ with excretion of $\psi$ (Table 2, Fig. $2 C$ ). After removing one remarkably high value of $690 \mathrm{pmol} 8$-oxodG/d/kg BW in the oldest age group the correlations with RMR and EI shift from $\mathrm{r}^{2}=$

Table 1. Body weight (BW), body mass index (BMI), resting metabolic rate (RMR), energy intake (EI) as well as urinary excretion rates of 8-oxo-2'-deoxyguanosine (8-oxodG), pseudouridine $(\psi)$ and $\gamma$-carboxyglutamic acid $($ Gla) in 3-18 years old boys

\begin{tabular}{|c|c|c|c|c|c|c|c|}
\hline $\begin{array}{c}\text { Age group } \\
\text { (No. of Subjects) }\end{array}$ & $\begin{array}{l}\text { BW } \\
(\mathrm{kg})\end{array}$ & $\begin{array}{c}\text { BMI } \\
\left(\mathrm{kg} / \mathrm{m}^{2}\right)\end{array}$ & $\begin{array}{c}\mathrm{RMR} \\
(\mathrm{kJ} / \mathrm{d} / \mathrm{kg})\end{array}$ & $\begin{array}{c}\mathrm{EI} \\
(\mathrm{kJ} / \mathrm{d} / \mathrm{kg})\end{array}$ & $\begin{array}{c}\text { Excretion of } \\
\text { 8-oxodG } \\
\text { (pmol/d/kg) }\end{array}$ & $\begin{array}{c}\text { Excretion of } \psi \\
(\mu \mathrm{mol} / \mathrm{d} / \mathrm{kg})\end{array}$ & $\begin{array}{c}\text { Excretion of } \\
\text { Gla } \\
(\mu \mathrm{mol} / \mathrm{d} / \mathrm{kg})\end{array}$ \\
\hline \multicolumn{8}{|l|}{3 у $(n=9)$} \\
\hline $\begin{array}{l}\text { Mean } \pm \text { SD } \\
6 \text { y }(n=8)\end{array}$ & $16.1 \pm 1.0$ & $15.9 \pm 0.9$ & $226.2 \pm 7.9$ & $336.6 \pm 50.5$ & $370.5 \pm 118.1$ & $7.9 \pm 0.8$ & $1.18 \pm 0.15$ \\
\hline Mean \pm SD & $23.0 \pm 4.7$ & $15.9 \pm 1.9$ & $189.6 \pm 16.9$ & $294.8 \pm 39.5$ & $432.5 \pm 103.8$ & $7.7 \pm 1.2$ & $1.09 \pm 0.15$ \\
\hline $10 \mathrm{y}(n=9)$ & & & & & & & \\
\hline $\begin{array}{r}\text { Mean } \pm \text { SD } \\
14 \text { y }(n=9)\end{array}$ & $33.5 \pm 4.8$ & $16.4 \pm 1.4$ & $157.7 \pm 12.4$ & $259.2 \pm 42.3$ & $373.5 \pm 56.2$ & $6.3 \pm 0.6$ & $0.78 \pm 0.10$ \\
\hline $\begin{array}{c}\text { Mean } \pm \text { SD } \\
18 \text { y }(n=9)\end{array}$ & $52.9 \pm 9.4$ & $19.0 \pm 2.2$ & $127.9 \pm 11.4$ & $185.9 \pm 53.7$ & $285.5 \pm 73.5$ & $5.7 \pm 0.6$ & $0.86 \pm 0.17$ \\
\hline Mean \pm SD & $70.3 \pm 7.0$ & $21.9 \pm 1.6$ & $113.5 \pm 3.9$ & $168.7 \pm 25.0$ & $334.7 \pm 142.9$ & $4.9 \pm 0.6$ & $0.69 \pm 0.09$ \\
\hline
\end{tabular}




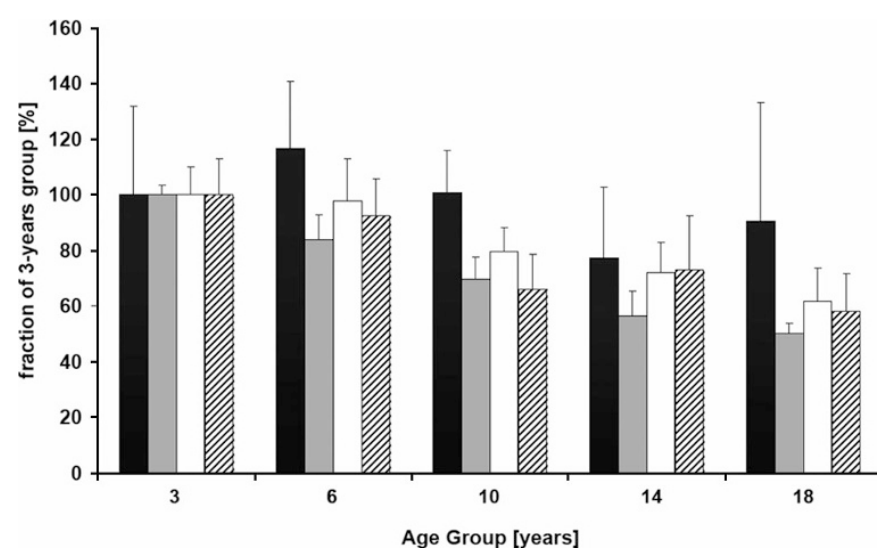

Figure 1. RMR $\square$ and urinary excretion of 8-oxodG $\square, \psi \square$, and Gla Z7 in 3-, 6-, 10-, 14-, and 18-y-old boys (mean $\pm \mathrm{SD}$ ). Data are given as fractions of the $3-y$ group.

$0.11-0.22$ and $0.25(p=0.0015$ and $p=0.001)$, respectively, which are also lower than the corresponding correlations of degradation of RNA and proteins with RMR and EI.

\section{DISCUSSION}

This study shows for the first time in an homogeneously composed group of 44 healthy 3-18-y-old boys that wholebody degradation rates of RNA and of Gla-containing proteins as well as of oxidative stress to DNA per $24 \mathrm{~h}$ per $\mathrm{kg} \mathrm{BW}$ are significantly correlated with RMR and dietary EI by food per $24 \mathrm{~h}$ per $\mathrm{kg} \mathrm{BW}$. The composition of the study group was chosen such as to reduce a possible influence of confounding factors on the excretion especially of 8-oxodG like gender, age, and lifestyle. Homogeneity of the five different age groups is reflected by relatively low coefficients of variation in the range of $6-12 \%$ for body mass index, $4-9 \%$ for RMR, $10-16 \%$ for $\psi$ excretion and $13-20 \%$ for Gla excretion (cal- culated by SD/mean $\times 100$; Table 1 ). Furthermore, differences of age between the subgroups were similar.

Correlation with metabolic rate is strongest for excretion of the RNA catabolite $\psi$ and weakest for 8-oxodG excretion. Strong relationships of resting energy turnover with RNA and protein turnover have been already shown in our previous studies $(27-30,32)$. In addition, this study reveals strong relationships of dietary EI, which in part serves as energy source of RMR with RNA and protein turnover. The method used for determining EI intake was weighing the ingested food components over 3 consecutive days and calculating the energy of the ingested food using published data on energy content of various food components. This method can be regarded as the gold standard of nutritional survey methods $(33,34)$. The relatively weak correlation between RMR and 8-oxodG excretion indicates that the $\mathrm{O}_{2}$ consumption indeed has an influence on oxidative DNA stress via ROS but that other additional factors cause the total amount of 8-oxodG in urine. In a cold stress experiment, we have found in rats that a $50 \%$ increase in $\mathrm{O}_{2}$ consumption over $6 \mathrm{~d}$ leads to elevated 8-oxo-dG excretion of only $13 \%$ (38).

A previous study was performed by us in a heterogeneously composed group of 14 children and 16 adults of both genders, aged from 7-41 y, to study the correlations between 8-oxodG excretion/d/kg LBM and RMR as measured by indirect calorimetry per LBM (27). In that study we found no significant correlation between both parameters and also high individual 8-oxodG excretion values of approximately 700-800 pmol 8 -oxodG per/d/kg LBM were observed in three adults. Why some of the individuals excrete such high 8-oxodG amounts remains currently speculative. They might have a relative high load ROS of DNA because of lifestyle (16) or a relatively low antioxidative protection. In both of our studies, the subjects lived under usual conditions of daily routine with food inges-

Table 2. Correlations $\left(r^{2}\right)$ between urinary excretion rates of 8-oxo-2'-deoxyguanosine (8-oxodG), pseudouridine ( $\psi$ ) or $\gamma$-carboxyglutamic acid $(G l a)$ and resting metabolic rate (RMR) and energy intake (EI) in 3-18 y old boys $(n=44)$

\begin{tabular}{|c|c|c|c|}
\hline Parameters correlated & Excretion of 8-oxodG (pmol/d/kg BW) & Excretion of Gla $(\mu \mathrm{mol} / \mathrm{d} / \mathrm{kg} \mathrm{BW})$ & Excretion of $\psi(\mu \mathrm{mol} / \mathrm{d} / \mathrm{kg} \mathrm{BW})$ \\
\hline RMR (kJ/d/kg BW) & $0.108(p=0.029)$ & $0.552(p<0.0001)$ & $0.691(p<0.0001)$ \\
\hline $\mathrm{EI}(\mathrm{kJ} / \mathrm{d} / \mathrm{kg} \mathrm{BW})$ & $0.108(p=0.036)$ & $0.462(p<0.0001)$ & $0.602(p<0.0001)$ \\
\hline Excretion of $\psi(\mu \mathrm{mol} / \mathrm{d} / \mathrm{kg} \mathrm{BW})$ & $0.174(p=0.005)$ & $0.709(p<0.0001)$ & - \\
\hline
\end{tabular}
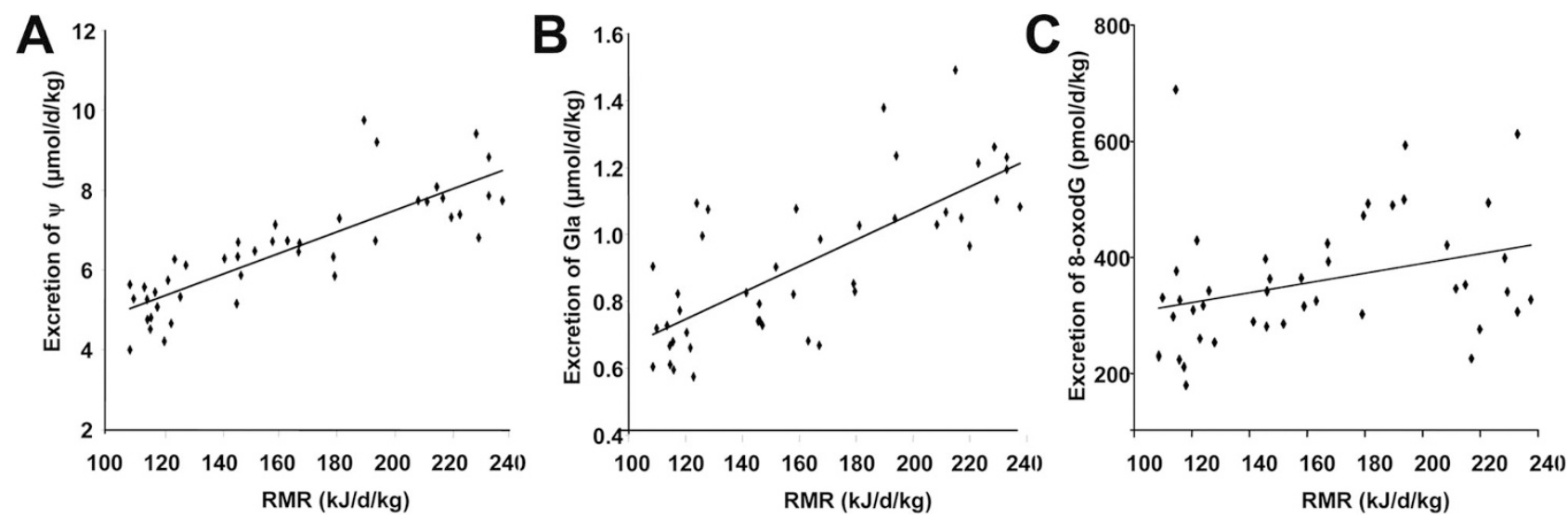

Figure 2. Regression lines between the calculated resting metabolic rate, RMR, and the urinary excretion rates of pseudouridine $(\psi), \mathrm{r}^{2}=0.691, p<0.0001$ $(A), \gamma$-carboxyglutamic acid (Gla), $\mathrm{r}^{2}=0.552, p<0.0001(B)$, and 8-oxo-2'-deoxyguanosine (8-oxodG), $\mathrm{r}^{2}=0.108, p=0.029(C)$, in 3-18-y-old boys. 
tion ad libitum. Furthermore, 8-oxodG residues in DNA are eliminated from DNA by different enzymatic repair mechanisms (glycosylase, nucleotide excision repair) leading to the excretion of both the nucleobase 8-oxoguanine (8-oxoGua) and nucleoside 8 -oxodG $(17,39)$. Therefore, different interindividually extent of glycosylase/nucleotide excision repair may also contribute to interindividually different excretion of 8-oxoGua and 8-oxodG. However, it has been shown in rats that excretion of 8-oxoGua in urine is not a suitable marker of endogenous oxidative stress to DNA at least in this species because it stemmed considerably from ingested food, unless this was free from nucleic acid $(3,4)$. In contrast, later performed investigations in humans have indicated that urinary excretion of 8-oxoGua is not influenced by dietary 8-oxoGua, and hence in humans urinary 8-oxoGua has been regarded as an appropriate marker of oxidative stress $(40,41)$. Furthermore, it is not known to what extent 8 -oxodG in urine originates either from DNA repair, and hence represents previous DNA damage, or is formed by oxidation of $\mathrm{dG}$ residues in the free nucleotide pool followed by decomposition of oxidized nucleotides to 8-oxodG by 8-oxo- $2^{\prime}$-deoxyguanosine-5'-triphosphate phosphatase(s) and 8-oxo- $2^{\prime}$ deoxyguanosine- $5^{\prime}$-monophosphate nucleotidase(s) $(5,42-$ 44). Therefore, it may better to regard 8-oxodG in urine as a potential marker for oxidative stress to DNA and the dNTP pool and not as a pure marker of oxidative DNA damage. Consequently, relatively high concentration of damage in the dNTP pool may contribute to high 8-oxodG excretion.

A further reason for the fact that we have found any correlation between 8-oxodG excretion and RMR in our previous (27) and recent studies may be because of the differences in the study groups of both studies. Whereas the collective in our previous study was composed of males and females from different regions in Germany, the collective of the present study consisted of males living in or near the same town (Dortmund, Germany). They were voluntary participants of the DONALD study in which nutrition and development of children and adolescents from Dortmund is investigated (33). Although, food in this collective was also ad libitum, parents of these children may be generally more interested in health and nutrition and may serve generally more benefit diets. Loft et al. (23) previously described a close association between 8-oxodG excretion and $\mathrm{O}_{2}$ consumption in 33 smoking and nonsmoking healthy premenopausal women, which were under a controlled diet and physical activity program. In contrast to our recent study (27) in which 14 children (age: median $10.6 \mathrm{y}$, range, $7.3-14.8 \mathrm{y}$ ) and 16 adults (age: median $29.8 \mathrm{y}$, range, 24.8-41.3 y) of both genders were investigated the collective of the present study consisted of five age groups with 8-10 male subjects/group. Hence, the more homogenous distribution from younger to older subjects of the same gender with decreasing RMR (Table 1) and the broader range of age of the children may contribute to the significant correlation of RMR with 8-oxodG excretion in this study. In a recently published study investigating biomarkers for oxidative stress in 100 healthy Japanese female and male subjects from 1.5-21 y, a decrease in 8-oxodG excretion in the formed different age groups (1-6, 6-11, 11-16, 16-21 y) has been described (45).
Coefficients of variation in the different groups were between 23 and $39 \%$ and thus in the range of our observed figures. However, it has been demonstrated before that determinations of urinary 8-oxodG with this enzyme-linked immunosorbent assay using the monoclonal antibody N45.1 yields values, which were on an average higher by a factor of 2 than the corresponding values determined by HPLC. For unknown reasons, $10 \%$ of the urine samples showed more than a 4-fold increase in value by ELISA and it has been suggested that the monoclonal antibody used is not sufficiently specific to detect 8 -oxodG in urine without prior purification of the samples (46). In addition 8-oxodG values in the study by Tamura et al. (45) were related to urinary creatinine stemming from energy turnover of muscle and it must be considered that muscle mass and hence urinary excretion of creatinine is lower in young (1-6-y old) children when compared with younger adult subjects aged 16-21 y (47). In our study, 8-oxodG was determined using quantitatively collected urine samples enabling to calculate 8-oxodG excretion per $24 \mathrm{~h}$ per $\mathrm{kg} \mathrm{BW}$.

Recently, the effect of aging on the level of 8-oxodG in leukocyte DNA was investigated in four age groups of healthy humans of on an average 13,31,50, and $67 \mathrm{y}$ by Siomek et al. (48). There was a highly significant rise in the mean level of 8-oxodG in leukocyte DNA in the elderly group (67 y) and middle-aged group $(50 \mathrm{y})$ in comparison with the adult group aged $31 \mathrm{y}$. However, a steady increase in 8-oxodG level in DNA was observed only when the youngest group (13 y) was excluded, as the mean 8-oxodG level was significantly elevated in the youngest subjects compared with the adult group aged $31 \mathrm{y}$. It has been inferred that the unexpected high level of oxidative DNA damage in the children may reflect the higher metabolic rate of children. In addition to the analysis of the background level of 8-oxodG in leukocytes DNA, urinary excretion of 8-oxoGua and 8-oxodG per creatinine was also determined. Because the urinary parameters showed a similar age-related pattern like 8-oxodG in leukocyte DNA, the authors concluded that the observed changes in the adult groups probably reflect, at least in part, an age-dependent intensification of oxidative stress which resulted in DNA damage. However, it has not been excluded by the authors that the results of this study may also reflect some deterioration of the repair mechanism(s) with increasing age, because the observed changes in age-dependent urinary excretion rates of 8-oxoGua and 8-oxodG were less distinct than those of background level of 8-oxodG in DNA. Interestingly, in the different age groups high interindividual differences were also described in the level of 8-oxodG in leukocyte DNA as well as urinary 8-oxoGua and 8-oxodG (e.g., in the 31-y group the coefficients of variation amounted to approximately $40 \%$ ). These results as well as the results of our present study, indicate highly individual different oxidative stress to DNA/ dNTP pool within a given age group. Unfortunately, we were not able to compare the urinary excretion of 8-oxodG in the 3-18-y-old subjects with 8-oxodG levels in DNA of leukocytes, as has been done in the above-mentioned study in older volunteers (48).

It remains speculative which factors were responsible for the different outcome of our present and former study inves- 
tigating 8-oxodG excretion and RMR in humans (27), e.g., environment, age, gender, different endogenous capacity to detoxify ROS or life style including ingestion of oxidative and antioxidative food components. In conclusion, this study reveals that the most established noninvasive marker for oxidative stress to DNA/dNTP pool by ROS is weaker correlated with the metabolic rate than the excretion rates of the RNA and protein catabolites $\psi$ and Gla suggesting that the excretion rate of 8-oxodG is influenced by other factors resulting in a relatively low coefficient of correlation between 8-oxodG excretion and metabolic rate. Identifying other potential factors affecting excretion of 8-oxodG, especially nutritional factors, should be the objective of further studies.

Acknowledgments. The authors thank Monika Hoyer and Daniela Hoffmeister for their excellent technical assistance.

\section{REFERENCES}

1. Ames BN, Shigenaga MK 1993 Oxidants are a major contributor to cancer and aging. In: Halliwell B, Aruoma OI (eds) DNA and Free Radicals. New York: Ellis Horwood, pp 1-15

2. Halliwell B, Whiteman M 2004 Measuring reactive species and oxidative damage in vivo and in cell culture: how should you do it and what do the results mean? $\mathrm{Br} \mathrm{J}$ Pharmacol 142:231-255

3. Beckman KB, Ames BN 1997 Oxidative decay of DNA. J Biol Chem 272:1963319636

4. Helbock HJ, Beckman KB, Shigenaga MK, Walter PB, Woodall AA, Yeo HC, Ames BN 1998 DNA oxidation matters: the HPLC-electrochemical detection assay of 8-oxo-deoxyguanosine and 8-oxo-guanine. Proc Natl Acad Sci USA 95:288-293

5. Loft S, Poulsen HE 1996 Cancer risk and oxidative DNA damage in man. J Mol Med 74:297-312

6. Cerutti PA 1994 Oxy-radicals and cancer. Lancet 344:862-863

7. Shigenaga MK, Gimeno CJ, Ames BN 1989 Urinary 8-hydroxy-2'-deoxyguanosine as a biological marker of in vivo oxidative DNA damage. Proc Natl Acad Sci USA 86:9697-9701

8. Park EM, Shigenaga MK, Degan P, Korn TS, Kitzler JW, Wehr CM, Kolachana P, Ames BN 1992 Assay of excised oxidative DNA lesions: isolation of 8-oxoguanine and its nucleoside derivates from biological fluids with a monoclonal anti-body column. Proc Natl Acad Sci USA 89:3375-3379

9. Helbock HJ, Thompson J, Yeo H, Ames BN $1996 \mathrm{~N}^{2}$-Methyl-8-oxoguanine: a tRNA urinary metabolite-role of xanthine oxidase. Free Radic Biol Med 20:475-481

10. Loft S, Deng XS, Tuo J, Wellejus A, Sørensen M, Poulsen HE 1998 Experimental study of oxidative DNA damage. Free Radic Res 29:525-539

11. Cooke MS, Evans MD, Podmore ID, Herbert KE, Mistry N, Mistry P, Hickenbotham PT, Hussieni A, Griffiths HR, Lunec J 1998 Novel repair action of vitamin C upon in vivo oxidative DNA damage. FEBS Lett 439:363-367

12. Tagesson C, Källberg M, Klintenberg C, Starkhammar H 1995 Determination of urinary 8-hydroxydeoxyguanosine by automated coupled-column high performance liquid chromatography. A powerful technique for assaying in vivo oxidative DNA damage in cancer patients. Eur J Cancer 31A:934-940

13. Kasai H 1997 Analysis of a form of oxidative DNA damage, 8-hydroxy-2'deoxyguanosine, as a marker of cellular oxidative stress during carcinogenesis. Mutat Res 387:147-163

14. Deng XS, Tuo J, Poulsen HE, Loft S 1998 Prevention of oxidative DNA damage in rats by Brussels sprouts. Free Radic Res 28:323-333

15. Cooke MS, Evans MD, Herbert KE, Lunec J 2000 Urinary 8-oxo-2'deoxyguanosine-source, significance and supplements. Free Radic Res 32:381-397

16. Kasai H, Iwamoto-Tanaka N, Miyamoto T, Kawanami K, Kawanami S, Kido R, Ikeda M 2001 Lifestyle and urinary 8-hydroxydeoxyguanosine, a marker of oxidative DNA damage: effects of exercise, working conditions, meat intake, body mass index and smoking. Jpn J Cancer Res 92:9-15

17. Cooke MS, Evans MD, Lunec J 2002 DNA repair: insights from urinary lesion analysis. Free Radic Res 36:929-932

18. Shoji H, Oguchi S, Shimizu T, Yamashiro Y 2003 Effect of human breast milk on urinary 8-hydroxy-2'-deoxyguanosine excretion in infants. Pediatr Res 53:850-852

19. Tsukahara H, Jiang MZ, Ohta N, Sato S, Tamura S, Hiraoka M, Maeda M, Mayumi M 2004 Oxidative stress in neonates: evaluation using specific biomarkers. Life Sci 75:933-938

20. Beckman KB, Ames BN 1998 Mitochondrial aging. Open questions. Ann N Y Acad Sci 854:118-127
21. Chance B, Sies H, Boveries A 1979 Hydroperoxide metabolism in mammalian organs. Physiol Rev 59:527-605

22. Hansford RG, Hogue BA, Mildaziene V 1997 Dependence of $\mathrm{H}_{2} \mathrm{O}_{2}$ formation by rat heart mitochondria on substrate availability and donor age. J Bioenerg Biomembr 29:89-95

23. Loft S, Astrup B, Buemann B, Poulsen HE 1994 Oxidative DNA damage correlates with oxygen consumption in humans. FASEB J 8:534-537

24. Loft S, Fischer-Nielsen A, Jeding IB, Vistisen K, Poulsen HE 1993 8-Hydroxydeoxyguanosine as a urinary biomarker of oxidative DNA damage. J Toxicol Environ Health 40:391-404

25. Foksinski M, Rozalski R, Guz J, Ruszkowska B, Sztukowska P, Piwowarski M, Klungland A, Olinski R 2004 Urinary excretion of DNA repair products correlates with metabolic rates as well as with maximum life spans of different mammalian species. Free Radic Biol Med 37:1449-1454

26. Lengger C, Schöch G, Topp H 2000 A high-performance liquid chromatographic method for the determination of 8-oxo-7,8-dihydro-2'-deoxyguanosine in urine from man and rat. Anal Biochem 287:65-72

27. Topp H, Armbrust S, Lengger C, Schöch G, Davies J, Stichler W, Manz F, Fusch C 2002 Renal excretion of 8-oxo-7,8-dihydro-2'-deoxyguanosine, degradation rates of RNA and metabolic rate in humans. Arch Biochem Biophys 402:31-37

28. Topp H, Schöch G 2000 Whole-body degradation rates of transfer-, ribosomal-, and messenger ribonucleic acids and resting metabolic rate in 3- to 18-year-old humans. Pediatr Res 47:163-168

29. Schöch G, Topp H, Held A, Heller-Schöch G, Ballauff A, Manz F, Sander G 1990 Interrelation between whole-body turnover rates of RNA and protein. Eur J Clin Nutr 44:647-658

30. Schöch G, Topp H 1994 Interrelations between degradation rates of RNA and protein and the energy turnover rates. In: Räihä NCR (ed) Protein Metabolism During Infancy. New York: Raven Press, pp 49-52

31. Waterlow JC 1984 Protein turnover with special reference to man. Q J Exp Physiol 69:409-438

32. Topp H, Iontcheva V, Schöch G 1998 Renal excretion of $\gamma$-carboxyglutamic acid and metabolic rate in 3-18 years old humans. Amino Acids 14:371-377

33. Kroke A, Manz F, Kersting M, Remer T, Sichert-Hellert W, Alexy U, Lentze MJ 2004 The DONALD Study. History, current status and future perspectives. Eur J Nutr 43:45-54

34. Kersting M, Sichert-Hellert W, Lausen B, Alexy U, Manz F, Schöch G 1998 Energy intake of 1 to 18 year old German children and adolescents. Z Ernahrungswiss 37:47-55

35. Schofield WN 1985 Perdicting basal metabolic rate new standards and review of previous work. Hum Nutr Clin Nutr 39:5-41

36. Kuo KC, Phan DT, Williams N, Gehrke CW 1990 Ribonucleosides in biological fluids by a high-resolution quantitative RPLC-UV method. In: Gehrke CW, Kuo KC (eds) Chromatography and Modification of Nucleosides, Part C. Amsterdam: Elsevier, pp C41-C113

37. Topp H, Duden R, Schöch G 1993 5,6-Dihydrouridine: a marker ribonucleoside for determining whole body degradation rates of transfer RNA in man and rats. Clin Chim Acta 218:73-82

38. Topp H, Lengger C, Schöch G, Werner J, Mietsch E 2000 Renal excretion of 8-oxo-7,8-dihydro- $2^{\prime}$-deoxyguanosine in Wistar rats with increased $\mathrm{O}_{2}$ consumption due to cold stress. Arch Biochem Biophys 376:328-332

39. Vogel U, Moller P, Dragsted L, Loft S, Pedersen A, Sandström B 2002 Interindividual variation, seasonal variation and close correlation of OGG1 and ERCC1 mRNA levels in full blood from healthy volunteers. Carcinogenesis 23:1505-1509

40. Gackowski D, Rozalski R, Roszkowski K, Jawien A, Foksinski M, Olinski R 2001 8-Oxo-7,8-dihydroguanine and 8-oxo-7,8-dihydro-2'-deoxyguanosine levels in human urine do not depend on diet. Free Radic Res 35:825-832

41. Cooke MS, Evans MD, Dove R, Rozalski R, Gackowski D, Agnieszka S, Lunec J, Olinski R 2005 DNA repair is responsible for the presence of oxidatively damaged DNA lesions in urine. Mutat Res 574:58-66

42. Mo JY, Maki H, Sekiguchi M 1992 Hydrolytic elimination of a mutagenic nucleotide, 8-oxodGTP, by human 18-kilodalton protein: sanitization of nucleotide pool. Proc Natl Acad Sci USA 89:11021-11025

43. Hayakawa H, Taketomi A, Sakumi K, Kuwano M, Sekiguchi M 1995 Generation and elimination of 8-oxo-7,8-dihydro-2'-deoxyguanosine-5'-triphosphate, a mutagenic substrate for DNA synthesis, in human cells. Biochemistry 34:89-95

44. Cooke MS, Olinski R, Loft S 2008 Measurement and meaning of oxidatively modified DNA lesions in urine. Cancer Epidemiol Biomarkers Prev 17:3-14

45. Tamura S, Tsukahara H, Ueno M, Maeda M, Kawarami H, Sekine K, Mayumi M 2006 Evaluation of urinary multi-parameter biomarker set for oxidative stress in children, adolescents and young adults. Free Radic Res 40:1198-1205

46. Shimoi K, Kasai H, Yokota N, Toyokuni S, Kinae N 2002 Comparison between high-performance liquid chromatography and enzyme-linked immunosorbent assay for the determination of 8-hydroxy-2'-deoxyguanosine in human urine. Cancer Epidemiol Biomarkers Prev 11:767-770

47. Remer T, Neubert A, Maser-Gluth C 2002 Anthropometry-based reference values for 24-h urinary creatinine excretion during growth and their use in endocrine and nutritional research. Am J Clin Nutr 75:561-569

48. Siomek A, Gackowski D, Rozalski R, Dziaman T, Szpila A, Guz J, Olinski R 2007 Higher leukocyte 8-oxo-7,8-dihydro-2'-deoxyguanosine and lower plasma ascorbate in aging humans. Antioxid Redox Signal 9:143-150 